\title{
Kaitan Pembelajaran Bahasa Indonesia dengan Lingkungan
}

\author{
Sekar Arum/19016123
}

\author{
sekararummaret@gmail.com
}

\begin{abstract}
Penggunaan bahasa tidak bisa terlepas pada saat bersosialisasi dengan lingkungan sekitar. Begitu pula dalam pembelajaran bahasa Indonesia, lingkungan sangat berpengaruh dalam proses pembelajaran siswa. Kaitan antara lingkungan dengan pembelajaran bahasa Indonesia sangatlah erat dan saling melengkapi satu sama lainnya. Menurut Dardjowidjojo (dalam Ramadhan et al, 2019) secara alamiah anak akan mengenal bahasa sebagai cara berkomunikasi dengan orang di sekitarnya. Bahasa pertama yang dikenal dan selanjutnya dikuasai oleh seorang anak disebut bahasa ibu (native language). Selanjutnya, Yogatama (dalam Ramadhan et al, 2019) mengatakan pemerolehan bahasa pertama sangat berkaitan dengan perkembangan sosial anak dan pembentukan identitas sosial. Mempelajari bahasa pertama merupakan salah satu perkembangan menyeluruh anak menjadi anggota suatu masyarakat.
\end{abstract}

Ramadhan et al (2019) mengatakan sejak usia dini, bayi telah berinteraksi di dalam lingkungan sosialnya. Seorang ibu seringkali memberi kesempatan kepada bayi untuk ikut dalam komunikasi sosial, maka pada saat itulah bayi pertama kali mengenal sosialisasi bahwa dunia ini adalah tempat orang saling berbagi rasa. Melalui bahasa pertama (B1), seorang anak belajar untuk menjadi anggota masyarakat. B1 menjadi salah satu sarana untuk mengungkapkan perasaan, keinginan, dan pendirian, dalam bentuk-bentuk bahasa yang dianggap ada. Anak belajar pula bahwa ada bentuk-bentuk yang tidak dapat diterima anggota masyarakatnya, anak tidak boleh selalu mengungkapkan perasaannya secara terus terang. Pemerolehan bahasa pertama atau bahasa ibu anak-anak di seluruh dunia sama. Kesamaan proses pemerolehan tidak hanya disebabkan oleh persamaan unsur biologi dan neurologi bahasa, tetapi juga oleh adanya aspek mentalitas bahasa Arifuddin (dalam Ramadhan et al, 2019).

Menurut Sukma (2020) tingkat rendah dari pengetahuan dan pemahaman informasi di Indonesia sering dikaitkan dengan rendahnya tingkat literasi masyarakat. Dalam pengertian ini, literasi dapat diartikan sebagai wawasan dan kemampuan individu untuk mengolah informasi dan pengetahuan untuk kecakapan hidup. Ramadhan et al (2019) menyatakan di Indonesia, sejalan dengan perubahan Kurikulum pada tahun 2013, pemerintah mencanangkan program Gerakan Literasi Sekolah (GLS) untuk meningkatkan literasi siswa. Gerakan tersebut tidak hanya ditujukan hanya untuk siswa saja, tetapi ditujukan untuk masyarakat pada umumnya. Terlepas dari hal tersebut, guru adalah komponen yang sangat menentukan dalam implementasi suatu strategi dalam mengefektifkan proses pembelajaran. Keberhasilan implementasi suatu strategi pembelajaran tergantung pada kepiawaian guru dalam menggunakan metode, teknik dan taktik mengajarnya Radesi (dalam Ramadhan et al, 2018). Walaupun demikian, hasil belajar menulis siswa masih rendah. Hal ini diakibatkan karena pada saat pembelajaran menulis berlangsung guru masih menggunakan bahan ajar yang kurang menarik, proses pembelajaran masih berpusat pada guru sehingga siswa tidak bisa belajar mandiri, padahal kemampuan, kecepatan, 
dan pemahaman siswa itu berbeda-beda dan guru masih mementingkan hasil dari pada proses (Ramadhan et al, 2015).

Ramadhan et al (2013) mengatakan bahwa usaha untuk mengetahui tingkat peran sikap dan motivasi belajar terhadap hasil belajar, khususnya pada pelajaran bahasa Indonesia, perlu dilakukan pengamatan dan analisis terhadap sikap dan motivasi belajar tersebut. Diketahuinya sikap dan motivasi belajar siswa, membantu para guru atau pihak sekolah dalam merumuskan berbagai strategi yang patut direncanakan dalam mengembangkan kegiatan belajar mengajar, terutama pada pelajaran bahasa Indonesia. Hal diatas dapat diatasi dengan mengembangkan individu yang sadar dan bertanggung jawab terhadap lingkungan diperlukan untuk menghadapi ini permasalahan sehingga lingkungan dan kualitas hidup yang berkelanjutan menjadi lebih baik. Ini bisa terwujud melalui pendidikan, lebih khusus lagi pendidikan lingkungan (Ramadhan et al, 2019).

Pendidikan lingkungan hidup adalah usaha bersama yang secara sadar diselenggarakan untuk mengajar atau menarik minat manusia perhatian tentang bagaimana fungsi lingkungan alam dan bagaimana manusia ini dapat mengelola dan melindungi itu. Seperti yang dikatakan oleh Ode (dalam Ramadhan et al, 2019) menjelaskan "kesantunan sebagai perilaku yang diekspresikan dengan cara yang baik atau beretika dan merupakan fenomena kultural, sehingga apa yang dianggap santun oleh suatu kultur mungkin tidak demikian halnya dengan kultur yang lain." Artinya kesantunan merupakan aspek kebahasaan yang amat penting karena dapat memperlancar interaksi antar individu. Pendidikan ini berlangsung dalam praktik mencari kreativitas dan penemuan, dan eksplorasi realitas tanpa disadari. Mengembangkan pengetahuan tentang ilmu pengetahuan dan sosial pentingnya lingkungan adalah langkah awal dalam pembentukan lingkungan yang ramah masyarakat.

Menurut Sukma (2020) satu solusi yang dapat dilakukan untuk mengatasi permasalahan lingkungan adalah dengan pengetahuan yang benar dari semua faktor lingkungan untuk menjaga lingkungan. Upaya paling efektif untuk mencapai ini Tujuannya adalah sistem pendidikan lingkungan yang memadai, dipetakan dan ditujukan untuk memberikan kesadaran, hati nurani dan informasi tentang masalah lingkungan kepada siswa dari semua tingkatan. Ditingkatkan kesadaran tentang lingkungan dapat diperoleh melalui proses pendidikan. Pendidikan adalah kuncinya elemen dalam pencegahan dan penyelesaian masalah lingkungan. Begitu juga dengan pembelajaran bahasa itu sendiri adalah fondasi di mana keterampilan akademik lainnya dibangun ( Sukma et al, 2020). Bahasa digunakan dalam berbagai bidang seperti ekonomi, hukum, politik, dan pendidikan. Di dalam pendidikan, khususnya pendidikan bahasa, pemanfaatan bahasa dikemas dalam empat keterampilan berbahasa yaitu menyimak, berbicara, membaca, dan menulis. Lebih lanjut, membaca merupakan keterampilan berbahasa dasar yang diperlukan untuk kehidupan akademik dan sosial. (Sukma et al, 2020). 
Berdasarkan angket yang penulis sebarkan mengenai "Kaitan Pembelajaran Bahasa Indonesia dengan Lingkungan" kepada sejumlah responden dengan total keseluruhan yaitu 36 responden dengan persentase responden pria sebanyak 5,6\% dan wanita sebanyak 94,4\%. Hasil data dari persentase angket yang telah dilakukan melalui google form tersebut dapat dilihat sebagai berikut. Pernyataan pertama, "Pengenalan lingkungan sangat berpengaruh terhadap pembelajaran bahasa Indonesia" 69,4\% menyatakan Sangat Setuju, 30,6\% menyatakan setuju, 0\% menyatakan kurang setuju, dan 0\% menyatakan tidak setuju. Pernyataan kedua, "Pengaplikasian bahasa Indonesia dapat diajarkan sejak dini dari lingkungannya, baik itu lingkungan formal maupun informal" 88,9\% menyatakan Sangat Setuju, 11,1\% menyatakan setuju, 0\% menyatakan kurang setuju, dan $0 \%$ menyatakan tidak setuju. Pernyataan ketiga, "Pengenalan pendidikan lingkungan penting untuk dimasukkan dalam pembelajaran guna menumbuhkan kesadaran peserta didik dalam menjaga lingkungan sekitar" $72,2 \%$ menyatakan Sangat Setuju, 27,8\% menyatakan setuju, 0\% menyatakan kurang setuju, dan $0 \%$ menyatakan tidak setuju. Pernyataan keempat, "Lingkungan memiliki pengaruh yang besar dalam perkembangan bahasa anak" $80,6 \%$ menyatakan Sangat Setuju, 19,4\% menyatakan setuju, $0 \%$ menyatakan kurang setuju, dan $0 \%$ menyatakan tidak setuju. Pernyataan kelima, "Pengintegrasian pendidikan lingkungan dalam proses pembelajaran bahasa Indonesia merupakan salah satu cara dalam mewujudkan dan mengembangkan kemampuan siswa, sehingga siswa dapat berinovasi dan berkolaborasi dengan lingkungan yang ada disekitar mereka" 61,1\% menyatakan Sangat Setuju, 38,9\% menyatakan setuju, 0\% menyatakan kurang setuju, dan 0\% menyatakan tidak setuju. Pernyataan keenam, "Kualitas pembelajaran bahasa Indonesia di ligkungan sekolah, dipengaruhi dengan metode belajar yang diterapkan oleh guru, dan minat siswa dalam pembelajaran" 58,3\% menyatakan Sangat Setuju, $33,3 \%$ menyatakan setuju, 8,3\% menyatakan kurang setuju, dan $0 \%$ menyatakan tidak setuju. Pernyataan ketujuh, "Melalui lingkungan, siswa mampu mengembangkan kemampuan ekologis, berpikir kreatif, inovatif, dan mampu meningkatkan kesadaran siswa pentingnya menjaga lingkungan" 63,9\% menyatakan Sangat Setuju, 36,1\% menyatakan setuju, $0 \%$ menyatakan kurang setuju, dan $0 \%$ menyatakan tidak setuju. Pernyataan kedelapan, "Dalam pembelajaran bahasa Indonesia di sekolah, guru harus memberikan pentingnya materi lingkungan dalam pembelajaran bahasa Indonesia di sekolah untuk menjagakelestarian lingkungan" 69,4\% menyatakan Sangat Setuju, $30,6 \%$ menyatakan setuju, $0 \%$ menyatakan kurang setuju, dan $0 \%$ menyatakan tidak setuju. Pernyataan kesembilan, "Masih minimnya tingkat kesadaran akan pentingnya lingkungan dalam pembelajaran Bahasa Indonesia" 36,1\% menyatakan Sangat Setuju, $50 \%$ menyatakan setuju, 8,3\% menyatakan kurang setuju, dan 5,6\% menyatakan tidak setuju. Dan pernyataan kesepuluh, "Kembali ke alam adalah rujukan yang tepat untuk menjadikan lingkungan (alam) sebagai sumber inspirasi untuk membangun kecerdasan kebahasaan" 41,7\% menyatakan Sangat Setuju, 44,4\% menyatakan setuju, $11,1 \%$ menyatakan kurang setuju, dan 2,8\% menyatakan tidak setuju.

Dari hasil penyebaran angket yang telah dilakukan, dapat penulis simpulkan bahwa lingkungan memiliki kaitan yang sangat erat dan penting dalam pembelajaran bahasa Indonesia. Terbukti saat para responden menganggap kaitan pembelajaran bahasa Indonesia dengan lingkungan merupakan suatu hal penting. Masyarakat, khususnya di kalangan mahasiswa dan pelajar, menyadari dan memahami eratnya kaitan lingkungan dalam pembelajaran bahasa Indonesia. Menurut penulis, kesadaran masyarakat terhadap kaitan lingkungan dalam pembelajaran bahasa Indonesia sudah dapat dikategorikan baik. Penerapan kaitan lingkungan dengan pembelajaran bahasa 
Indonesia tersebut dapat memudahkan guru dan siswa dalam mengajarkan dan memahami materi bahasa Indonesia yang memotivasi, kreatif, menyenangkan, dan bermanfaat. 


\section{DAFTAR PUSTAKA}

Gani, E., Noibe Halawa, dan Syahrul R. (2019). Kesantunan Berbahasa Indonesia Dalam Tindak Tutur Melarang Dan Mengkritik Pada Tujuh Etni. Jurnal Bahasa, Sastra, dan Pengajarannya, XV(2), 195-205.

Ramadhan, S., Elfia Sukma, dan Vivi Indriyani. (2019). Environmental Education and Disaster Mitigation Through Language Learning. IOP Conference Series: Earth and Environmental Science, 314, p. 1-9.

Ramadhan, S., Indah Permatasari Suardi, dan Yasnur Asri. (2019). Pemerolehan Bahasa Pertama pada Anak Usia Dini. Jurnal Obsesi : Jurnal Pendidikan Anak Usia Dini, 3(1), 265 - 273.

Ramadhan, S., Mina Syanti Lubis, dan Novia Juita. (2015). Pengembangan Modul Pembelajaran Bahasa Indonesia Berbantuan Peta Pikiran Pada Materi Menulis Makalah Siswa Kelas Xi Sma/Ma. Jurnal Bahasa, Sastra dan Pembelajaran, 2(1), 17-28.

Ramadhan, S., M. Zaim, Atmazaki, dan Vivi Indriyani. (2019). Literasi Baca Tulis Dan Inovasi Kurikulum Bahasa. Jurnal Keilmuan Bahasa, Sastra, dan Pengajarannya, 5(1), 108-118.

Ramadhan, S., Yuliana Sari, dan Yulianti Rasyid. (2018). Hubungan Antara Keterampilan Membaca Pemahaman Dengan Keterampilan Menulis Teks Laporan Hasil Observasi Siswa Kelas X Smk Negeri 3 Padang. Jurnal Pendidikan Bahasa dan Sastra Indonesia, 7(3), 446-453.

Sukma E. et. al. (2020). Compentency of Elementary School Teacher In Written Language Learning. 2300712.

Sukma E., Syahrul Ramadhan, dan Vivi Indriyani. (2020). Design of Learning Modules Writing Narrative Text Based on Project Based Learning (PjBL) by Using Mobile Devices. Journal of Physics: Conf, Series 1471, 1-9.

Sukma, E., Syahrul R, dan Vivi Indriyani. (2020). Integration of Environmental Education in Elementary Schools. Journal of Physics: Conf. Series 1481, 1-6.

Sukma E. et. al. (2019). Models of Literacy Media in Improving Reading Skill of Early Grade Students. Primary Teacher Education Program. 11-12.

Zulhafizh, Atmazaki, dan Syahrul Ramadhan. (2013). Kontribusi Sikap dan Motivasi Belajar Siswa terhadap Hasil Belajar Bahasa Indonesia. Jurnal Bahasa, Sastra dan Pembelajaran, Volume 1, Nomor 2, Halaman 13-28. 